\title{
THE RESPONSE OF THE NEWBORN INFANT TO MUSCLE RELAXANTS*
}

\author{
H C Churchill-Davidson, M A $\mathrm{d}, \mathrm{F}$ F A R S , \\ AND $\mathbb{R}$ P WISE, M B, BS, F F R RS
}

FOR SOME YEARS PASI the response of the neonate to relaxant drugs has been regarded as being dufferent from that of the average adult patient This clinical observation has led to the suggestion that the neonate responds to muscle relaxants in a manner similar to that of patients with myasthenia gravis ${ }^{1}$ In other words, the newborn would appear to be resistant to depolarizing drugs and extremely sensitive to non-depolarizing drugs $\mathrm{Bush}$ and $\mathrm{Stead}^{2}$ observed the dose of $d$-tubocurarme required to produce "adequate control of ventilation and satisfactory operating conditions" in a large series of newborn infants undergoing surgeny They concluded that only durmg the first ten days of life did the neonate show some "sensitivity" to $d$-tubocurarme

An attempt has been made to verify this hypothesis The response of the neonate to depolarizing drugs has already been reported ${ }^{3}$ It only remamed, therefore, to study the effect of non-depolarizing drugs in this group of patients

\section{METHOD}

Neuromuscular transmission was studied in three newborn infants (two female, one male) using a modification of the technique of Harvey and Masland (1941) as previously described by Churchill-Davidson and Richardson ${ }^{4} \mathrm{~b}$ The ulnar nerve at the elbow was stimulated supramaximally with needle electrodes at rates varying from 25 to 50 per second with a duration of 01 millisecond The action potentals of the contracting hypothenar muscles were recorded with needle electrodes and displayed on a cathode-ray oscilloscope A simultaneous photographic record on $35-\mathrm{mm}$ film was made and subsequently each action potential was examined under an enlarger and the height of the varıous potentrals expressed as a percentage of the first twitch control of the series

The following studies were made $(a)$ the effect of a dose of $d$-tubocurarine upon neuromuscular transmission, $(b)$ the effect of a dose of an anticholinesterase drug-neostigmine or edrophonium (Tensilon)--upon the neuromuscular block produced by $d$-tubocurarme

In order to prevent volitional activity each infant was anaesthetized with nitrous oxide and oxygen ( 41 , litres $/$ minute) to which 5 per cent $(250 \mathrm{ml} / \mathrm{min}$ ) of cyclopropane was occasionally added in order to maintain the lightest possible level of anaesthesia The gases were administered via a T-piece after endotracheal intubation, which was performed without anaesthesia Respiration was assisted when the ventilatory volume was judged to be madequate Body temperature was mantaned by the use of an incubator and a radiant-heat lamp

"From the Department of Anaesthetıcs, St Thomas's Hospital, London, S E 1, England 
All drugs were administered into a scalp vein on a body-weight basis, as calculated from the clinical dose required for an average adult patient of $64 \mathrm{~kg}$ (140 lb ), viz
D-tubocurarine chloride
Neostigmine methylsulphate Effective dose in adults is $25-50 \mathrm{mg}$ for full
Dose required to produce paralysis of hypo- thenar muscles in an adult patient $(64 \mathrm{~kg})=$ $12 \mathrm{mg}, 1 \mathrm{e}, 187 \mu \mathrm{g} / \mathrm{kg}$ anticholinesterase activity (preceded by $1 \mathrm{mg}$ atropine sulphate)
Edrophonium (Tensilon) $\begin{aligned} & \text { Eftective dose in adults is } 5-10 \mathrm{mg} \text { for full } \\ & \text { anticholınesterase activity }\end{aligned}$

\section{RESULTS}

Full details of the findings are given in Table I, and a typical response is shown in Figure 1 Certain aspects of these results, however, require further emphasis

TABLE I

CONTROL

\begin{tabular}{|c|c|c|c|c|c|c|}
\hline & Case no & $\begin{array}{l}\text { Age in } \\
\text { weeks }\end{array}$ & $\begin{array}{l}\text { Weight } \\
\text { in kg }\end{array}$ & $\begin{array}{c}\text { Height of } \\
\text { twitch } \\
\text { in Mv }\left(\phi_{0}\right)^{*}\end{array}$ & $\begin{array}{l}\text { Height of } \\
\text { tetanus }(\%)\end{array}$ & $\begin{array}{l}\text { Height of } \\
\text { twitch }(\%)\end{array}$ \\
\hline $\begin{array}{l}S E \\
M U \\
A K\end{array}$ & $\begin{array}{l}1 \\
2 \\
3\end{array}$ & $\begin{array}{l}1 \\
3 \\
2\end{array}$ & $\begin{array}{ll}3 & 0 \\
3 & 25 \\
3 & 1\end{array}$ & $\begin{array}{lll}5 & 5 & (115) \\
5 & 7(109) \\
3 & 3 & (100)\end{array}$ & $\begin{array}{l}115(112) \\
100(110) \\
108(122)\end{array}$ & $\begin{array}{r}115(115) \\
98(100) \\
110(115)\end{array}$ \\
\hline
\end{tabular}

AFTER $d$-TUBOCURARINE

\begin{tabular}{lcccccc}
\hline \hline & $\begin{array}{c}\text { Total dose } \\
\text { D T C } \\
\text { in } \mu \mathrm{g}\end{array}$ & $\begin{array}{c}\text { Time of admin } \\
\text { (from start) } \\
\text { 1n min }\end{array}$ & $\begin{array}{c}\text { Height of } \\
\text { twitch }(\%)\end{array}$ & $\begin{array}{c}\text { Height of } \\
\text { tetanus }(\%)\end{array}$ & $\begin{array}{c}\text { Height of } \\
\text { twitch }(\%)\end{array}$ \\
\hline $\mathrm{SE}$ & 1 & $450[560]$ & 4 & $12(12)$ & $15(11)$ & $12(12)$ \\
$\mathrm{M} \mathrm{U}$ & 2 & $600[610]$ & 7 & $30(15)$ & $40(17)$ & $52(25)$ \\
$\mathrm{A} \mathrm{K}$ & 3 & $500[580]$ & 13 & $65(35)$ & $72(45)$ & $105(80)$ \\
\hline
\end{tabular}

After NeOstigmine or Edrophonium

\begin{tabular}{|c|c|c|c|c|c|c|}
\hline & Case no & $\begin{array}{l}\text { Total dose } \\
\text { neostig or } \\
\text { edrophonium } \\
\text { 1n mg }\end{array}$ & $\begin{array}{c}\text { Time of admin } \\
\text { (from start) } \\
\text { in min }\end{array}$ & $\begin{array}{l}\text { Height of } \\
\text { twitch }(\%)\end{array}$ & $\begin{array}{l}\text { Height of } \\
\text { tetanus (\%) }\end{array}$ & $\begin{array}{l}\text { Herght of } \\
\text { twitch }(\%)\end{array}$ \\
\hline $\begin{array}{l}\text { SE } \\
\text { MU U } \\
\text { A K }\end{array}$ & $\begin{array}{l}1 \\
2 \\
3\end{array}$ & $\begin{array}{lll}0 & 150(\searrow) \\
0 & 148(\mathrm{~N}) \\
1 & 0 & (\mathrm{E})\end{array}$ & $\begin{array}{l}13 \\
10 \\
20\end{array}$ & $\begin{array}{r}110(112) \\
90(60) \\
100(100)\end{array}$ & $\begin{array}{r}130(95) \\
92(35) \\
105(112)\end{array}$ & $\begin{array}{r}110(102) \\
95(70) \\
115(100)\end{array}$ \\
\hline
\end{tabular}

*The height of the first action potentıal (twitch) of the control series (expressed here in millvolts) is taken to equal 100

The height of the fourth action potential of the series is represented as ( )

The equivalent dose $1 \mathrm{ng} / \mathrm{kg} \mathrm{BW}$ in adults required for paresis is expressed as [ ] 


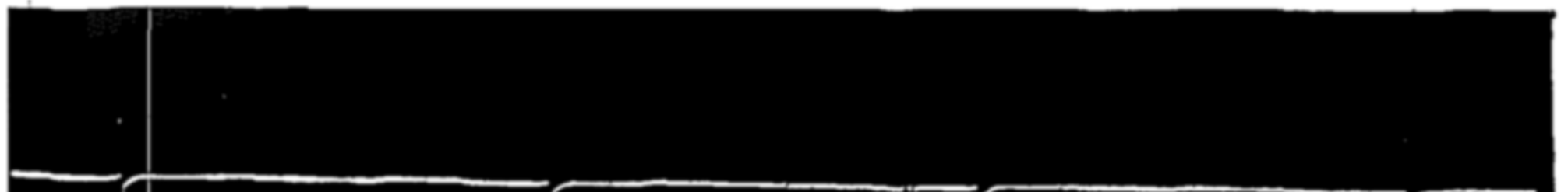

B
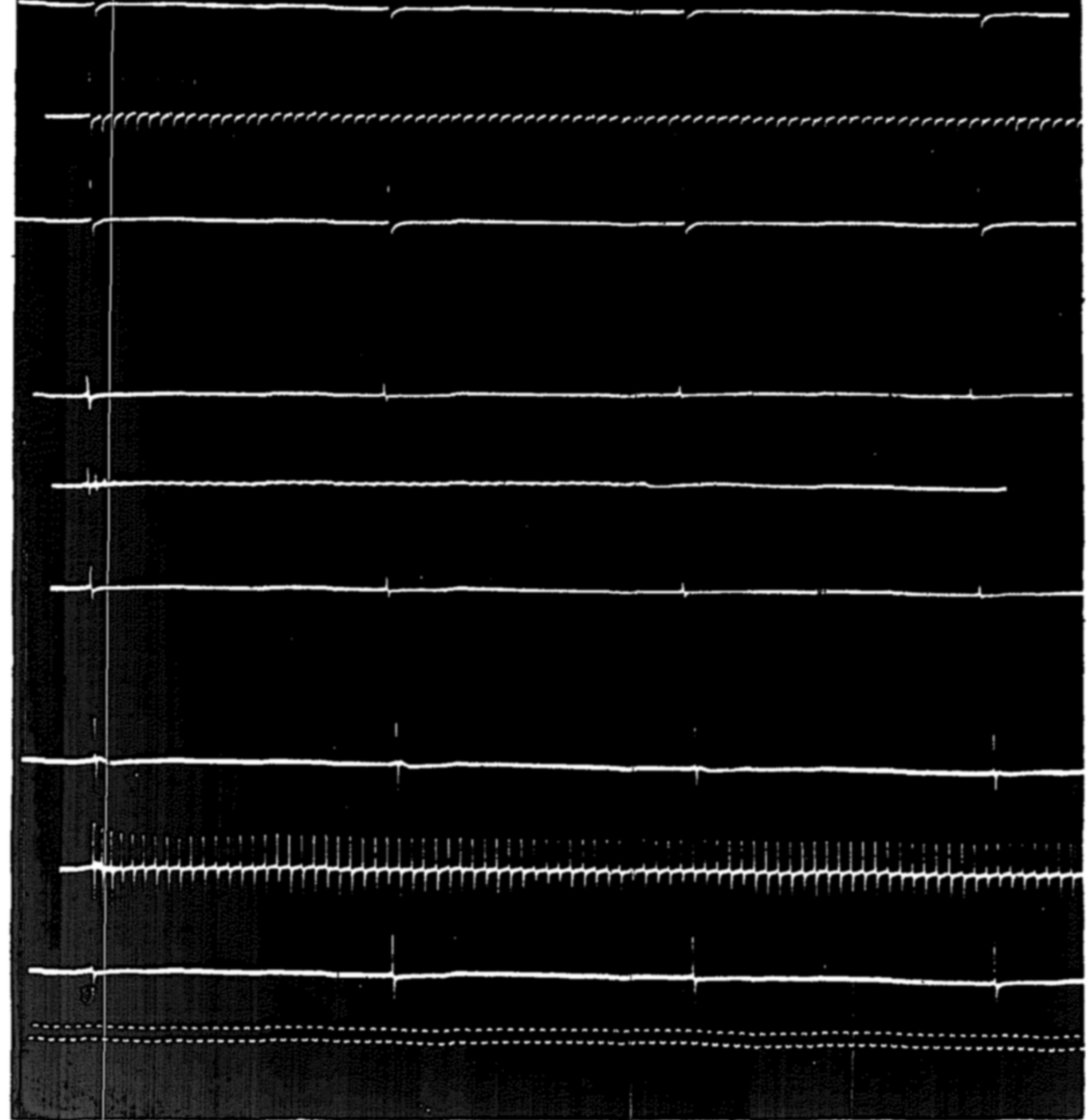

Ficure 1 Effect of $d$ tubocurarine and neostigmine in a neonate ( $M U$ ) A Control showng the effect of twitch rates of nerve stimulatiorr $(25 / \mathrm{sec})$ before and after tetanic stimulation $(50 / \mathrm{sec})$ B Same after administration of $600 \mu \mathrm{g} d$ tubocuranne picture taken at 9 th $\mathrm{m}$ 1 xute $\mathrm{C}$ Same four minutes after admunistration of $0148 \mathrm{mg}$ neostigmine methyl sulphate picture taken at 14 th minute $T$ ime base $=001$ second 


\section{(a) Sensitvity of the Hypothenar Muscles to d-Tubocurarne Chloride}

The dose of $d$-tubocurarine required to produce paralysis of the hand muscles in an average adult patient is about the same as that required for the neonate on a purely body-weight calculation (based on an average adult body-weight of $64 \mathrm{~kg}$ or $140 \mathrm{lb}$ )

During this examination a clinical observation was made that the respiratory tidal volume diminished part passu with the paresis in the hand muscles, whereas in the adult patient paralysis of the hand muscles can be produced without apparent reduction in the tidal volume

(b) Reversal of the Neuromuscular Bloch (d-Tubocurarne) by an Antrcholnesterase in the Neonate

The block produced by $d$-tubocurarine in the neonate was readnly reversed by a proportional dose of neostigmine methylsulphate and atropine sulphate (Fig 1C) or by edrophonum (Tensılon), but in the latter case the improvement was only short-lived

\section{DisCUSisION}

Although these findings can be interpreted as demonstrating that the response of the neonate to non-depolarizing relaxant drugs is very similar to what one has come to expect in the average adult patient, there is the possible exception of an increased susceptiblity of the respiratory muscles At this point it must be emphasized that this is only a clinical observation, and that no direct measurement of respiratory tidal volume was made Nevertheless, such a state of affairs might well explain the traditional view of anaes/hetists that the neonate is particularly sensitive to non-depolarizing drugs

This intimate relationship between the paralysis of the hand and respiratory muscles in the neonate could be explained in a number of ways, but only the two principal theones will be considered here The first theory suggests that the respiratory muscles in the neonate are genumely more sensitive to $d$-tubocurarme because of some particular property of the motor end-plate or muscle fibre The second hypothesis claims that the neonate possesses much less respiratory reserve than the adult This would mean that the neonate requires almost all its respinatory muscle fibres all the tume to produce a normal tidal volume, in other words the tidal volume of the neonate is approximately equal to its vital eapacity This is in marked contrast to the adult patient, where the tidal volume is normally about one-tenth of the vital capacity

Before considering neonatal neuromuscular transmission as a whole, it is necessary to recapitulate the principal features of the effert of a depolarizing drug (decamethonium) on the neonate ${ }^{3}$

I The neonate has a tolerance or resistance to depolauzing drugs, which (on a body-weight basis) is comparable to 2-3 tumes the adult dose for the same degree of paresus

2 In the premature and newboin infant the electromyographic leatures of the neuromuscular block produced by decarnethonum ale not those of pure de- 
polarization but are of the "dual" type similar to that described for cases of myasthenıa gravis This characteristic is most easily detected in the premature infant and gradually disappears during the first few months of life

Neonatal neuromuscular transmission, therefore, would seem to be different from that observed in adult patients There are many similanties, however, to that found in patients with myasthenia gravis One of the principal features of cases of myasthenia is that the muscles can broadly be classified into two groupsthose that are clinically weak and give way to a "dual" type of block on the injection of a depolarizing drug, and those that are not clinically weak and show a resisiance to depolarizing drugs In very mild cases of myasthenia only a few muscles of the body-such as the eyelids-are affepted, and all the remanning muscles are found to be highly resistant to depolarizing drugs "The milder the myasthenia, the greater is this resistance found to be It is not difficult, therefore, to assume that there must be individuals who are leading perfectly normal lives, yet who have a marked resistance to depolarizmg diugs Such individuals might be described as "pre-myasthenic"

These studies in neonates suggest that the resistant phase of myasthenia may well be due to an arrest in phylogenetic development resulting in the persistence of neonatal neuromuscular transmission into adult life Thus, at any time, as a resuli of some unknown factor, the full picture of myasthenia gravis with its concomitant clinical weakness may develop This hypothesis can also be used to explain congenital myasthenid, which is a condition of severe muscle weakness developing at birth and responding to anticholinesterase therapy, yet which appears to remit spontaneously during the first few months of life

In conclusion, these studies suggest that the clinical use of repeated doses of succinylcholme in the neonate may lead to a dual block with all the difficulties of ireatment of prolonged inadequate ventilation that are sometumes encountered in the adult It is suggested, therefore, that $d$-tubocurarnne is a more suitable relaxant drug for producung prolonged relaxation in the newborn infant It should always be used sparingly and its accurate administration requires a drastic dilution Ver er theless, provided the motor end-plates are not excessively saturated by an overdose of $d$-tubocurarme, it appears that the neuromuscular block is readily reversible

\section{SUMMARY}

1 The injection of a non-depolarizing relaxant drug ( $d$-tubocurarime) in the neonate leads to a neuromuscular block similar to that observed in an adult patient

2 There was no evidence of increased sensitivity of the hand muscles of the neonate to $d$-tubocurame as compared with the adult The possibility of mereased "sensitivity" of the respiratory muscles is discussed

3 The simllarity between some aspects of neuromuscular transmission in the newborm and in patients with myasthenia gravis is devcribed

4 The suggestion is made that $d$-tubocurarme (well diluted) is more suitable than suxamethonum for producing muscular ielaxation in the neonate 


\section{RÉSUMMÉ}

L'injẹction d'un myorésolutif non dépolarisant ( $d$-tubocurarine) produit, chez le nouveau-né un blocage neuromuscularle identıque à celuı qu'on observe chez l'adulte

Par comparaison avec l'adulte, le nouvelau-né n'a pas présenté une plus grande sensibilité des muscles de la main à la $d$-tubocurarme Quant à la possibılité d'une plus grandè sensibilité des muscles respiratorres, elle est discutable

On décrit la ressemblance entre certaıns aspects de la transmission neuromuścularre chez le nouveau-né et chez le málade attemt de myasthénie grave - Il nous semble que la $d$-tubocurarine (bien diluée) est préférable au suxaméthonium pour produre la résolution muscularre chez le nouveau-né

\section{ACKNOWLEDGMENTS}

We should like to express our gratitude to Dr Brian Wilson and Dr. Denis Cottom for their co-operation and for permission to examine the patients under their care This work was done with the ald of a grant from the Medical Research Councll and from the Muscular Dystrophy Group We are grateful to $\mathrm{Mr}$ $T$ Brandon for the photographic records and to Miss Jean Davenport for secretarial assistance

\section{REFERENCES}

1 ReEs, G JACkson In General Anaesthesia, Vol 2 Edited by Evans, $\mathrm{F}$ T, and Gray, $\mathrm{T} \mathrm{C}$ London Butterworths (1959)

2 Bush, G H \& Stead, A L The Use of $d$-Tubocurarine in Neonatal Anaesthesia Brit J Anaesth 34,721 (1962)

3 Churchill-Davidson, H C \& Wise, R P Neguromuscular Transmission in the Newborn Infant Anesthesiology (in press, 1963)

4 Churchill-Davidson, H C \& Richardson, A T Decąmethonlum Iodide (C 10) Some Observations on Its Action Using Electromyography Proc Roy Soc Med 45, 179 (1952)

5 - - Neuromuscular Transmission in Myạsthenıa Gravis J Physiol (Lond) 122, 252 (1953) 